\title{
THE RIGHT TO A FAIR TRIAL IN AUTOMATED CIVIL PROCEEDINGS
}

\author{
by
}

MARIA DYMITRUK

\begin{abstract}
Challenges associated with the use of artificial intelligence (AI) in law are one of the most hotly debated issues today. This paper draws attention to the question of how to safeguard the right to a fair trial in the light of rapidly changing technologies significantly affecting the judiciary and enabling automation of the civil procedure. The paper does not intend to comprehensively address all aspects related to the right to a fair trial in the context of the automation of civil proceedings but rather seeks to analyse some legal concerns from the perspective of the Article 6 of the European Convention on Human Rights and the case-law of the European Court of Human Rights. Section 1 discusses the issues of using artificial intelligence in the justice and automation of the judicial proceedings. Section 2 is devoted to the judge supporting system based on artificial intelligence and psychological requirements of its practical use. Section 3 presents the right to a fair trial in civil cases established by the Article 6 of the European Convention on Human Rights, while subsequent sections characterize its elements with respect to the possibility to automate civil proceedings: a right to have case heard within a reasonable time in section 4 and a right to a reasoned judgment in section 5.
\end{abstract}

\section{KEY WORDS}

Artificial Intelligence, Automation, Civil Proceedings, Right to a Fair Trial

\section{INTRODUCTION}

The law and the judiciary are elements of social life. ${ }^{1}$ Their main purpose is to regulate interpersonal relations. Legal norms are meant to indicate what

maria.dymitruk@uwr.edu.pl; PhD student; Research Centre on Legal and Economic Issues of Electronic Communication; Faculty of Law, Administration and Economics; University of Wrocław, Poland. 
people shall or must do; what is forbidden or allowed to. The law could not fulfill its function if there were not for institutions providing its compliance (an application and an execution). The judiciary - one of three main branches of state's government - was assigned to perform this function. The justice system, as almost all modern spheres of social life, is currently experiencing changes caused by technological development. A lot of attention has been recently paid to the possibility to use the artificial intelligence (AI) tools in order to improve the judiciary. This concept is expressed both in scientific initiatives, ${ }^{2}$ as well as in the endeavors of the public authorities of some countries. ${ }^{3}$ Although a scientific research on the AI applications in law has been carried out since the $1970 \mathrm{~s},{ }^{4}$ many of the AI techniques require further study and in-depth analysis of their societal implications. Issues arising from the use of AI as a part of the legal decision-making process are manifold and complex. At the same time, the debate about its possible consequences both for individuals and societies is at an early stage. ${ }^{5}$ Nevertheless, it should not prevent efforts towards understanding the role of the judiciary and the human rights concerns in the context of the development of the artificial intelligence technologies.

This paper analyses the possibility to automate the civil proceedings by creating an artificial intelligence system, which is able to carry out

1 Quoting McGinnis and Pearce: "Law is an information technology - a code that regulates social life" (see McGinnis, J. O. and Pearce, R. G. (2014) The great disruption: how machine intelligence will transform the role of lawyers in the delivery of legal services. Fordham Law Review, 82 (6), p. 3041).

2 E.g. Floris Bex, Henry Prakken, Tom van Engers and Bart Verheij (eds.). (2017) special issue of Artificial Intelligence and Law Journal "AI4J". Artificial Intelligence and Law, 25 (1); Giovanni Sartor and Luther Karl Cranting (eds.). (1998) Judicial Applications of Artificial Intelligence. Dordrecht: Springer Netherlands; Barros, R. et al. (2018) Case Law Analysis with Machine Learning in Brazilian Court. In: Malek Mouhoub, Samira Sadaoui, Otmane Ait Mohamed and Moonis Ali (eds.). IEA/AIE 2018, Cham: Springer.

3 As an example, the Brazilian project-in-progress VICTOR aims to support the Brazilian Supreme Court by analysing the lawsuit cases that reach the Court, using document analysis and natural language processing tools. VICTOR is a project at the Brazilian Supreme Court, developed in a partnership with the University of Brasília. For more information see Victor. [online] Available from: http://gpam.unb.br/victor/ [Accessed 30 January 2019].

4 E.g. Buchanan, B. and Headrick, T. (1970) Some Speculation About Artificial Intelligence and Legal Reasoning. Stanford Law Review, 23 (1), pp. 40-62; McCarty, L. T. (1977) Reflections on "Taxman": An Experiment in Artificial Intelligence and Legal Reasoning. Harvard Law Review, 90, pp. 837-893.

5 Committee of experts on internet intermediaries (MSI-NET). (2018) Algorithms and Human Rights - Study on the human rights dimensions of automated data processing techniques (in particular algorithms) and possible regulatory implications. Council of Europe. Available from: https://rm.coe.int/algorithms-and-human-rights-en-rev/16807956b5

[Accessed 30 January 2019]. 
the judicial decision-making process. In this respect, artificial intelligence may be successfully used in two forms: as an independent adjudicating entity or as a judge's supporting tool. In the first model, the AI system shall settle legal cases unassisted (the system adjudicates instead of a human judge). The second model focuses on the use of AI as a judge-supporting system. Such a supporting tool should provide a judge with a final proposal of the decision after finding relevant provisions, analysis of the case-law and review of the doctrine.

The presented models of the automated civil proceedings are possible to be implemented from the technical point of view (at least in some civil cases). Nevertheless, both of them require prior detailed analysis of their compatibility with legal frameworks determining the shape and the functions of the civil procedure. What is important, both models have different level of a human judge involvement in the decision-making process. According to the model of AI as an independent adjudicating entity, the judge is not directly involved in the reasoning process of the system, which takes a binding legal decision unassisted. On the other hand, the judge's supporting model assumes that the system's proposal will be afterwards verified by human judge, who after assessing the decision with all his competences and knowledge, will consider the decision as:

(a) completely correct (and as a result, will issue identical decision);

(b) only partially correct (what will result with the necessity to change the content of the decision and possibly - issue a decision which is different from the system-suggested one);

(c) entirely incorrect (resulting in rejection of the system's proposal and the necessity to conduct separate legal reasoning and take a legal decision by a human judge).

Obviously, due to the complexity of the judicial decision-making process, the possibility to use AI as a judge-supporting system (when compared to the first model of unassisted decision-making) is much more realistic. Moreover, it can be implemented sooner. However, the research on the automation of the judicial proceedings shall not focus only on judicial decision support systems. In my opinion, in the future they will constitute only the first stage in the process of full automation of the judicial proceedings and possible creation of the AI-judge. Modern achievements 
in the field of AI \& law lead to the conclusion that use of artificial intelligence in the judiciary is a foreseeable future, and not only futurological issue. ${ }^{6}$

\section{QUASI-AUTOMATED DECISION-MAKING}

As indicated above, the automation of the civil proceedings may have two forms:

(a) of handing over the whole adjudicating process in hands of the AI system taking legal decisions, which are binding to parties to the proceedings; and

(b) using AI to create the judge's support system, which shall provide the judge with the proposal of the case settlement.

With regard to the second model, one may ask completely justified question: what influence on the existence of the right to a fair trial may have the fact, whether the judge is using any tools in his work or not? Despite appearances, also the use of $\mathrm{AI}$ in the judicial decision support systems is of great importance for obedience of the right to a fair trial. It might have seemed that this model is neutral to this right, as a decision-making process still remains in human's hands. However, it turns out that using AI only as a supporting tool for human judges may have an equivalent effect as the full automation of the civil proceedings. It is connected with psychological results of human behavior and the "persuasiveness" of the AI supporting systems.

The publication of the Council of Europe entitled "Algorithms and Human Rights - Study on the human rights dimensions of automated data processing techniques (in particular algorithms) and possible regulatory implications" prepared by the Committee of Experts on Internet Intermediaries (MSI-NET) in March 2018 correctly distinguishes fully automated decision-making (in which the decision is made by the AI system without participation of a human judge) and semi-automated decision-making (the system presents the suggested proposal, but it is the human who formally takes final decision). ${ }^{7}$ The authors of the publication have also accurately noticed

\footnotetext{
E.g. Estonia runs a project to introduce $\mathrm{AI}$ into the justice system. For more information see Niler, E. (2019) Can AI be a Fair Judge in Court? Estonia Thinks So. [online] Available from: https://www.wired.com/story/can-ai-be-fair-judge-court-estonia-thinks-so/ [Accessed 29 April 2019].

7 Committee of experts on internet intermediaries (MSI-NET), op. cit., p. 8.
} 
that the algorithms are increasingly used in the context of the civil and the criminal justice systems where artificial intelligence is being developed to eventually support or replace decision-making by human judges. ${ }^{8}$ An emphasis was also put on the fact that in cases where the human judge is supported by the algorithm-based system:

"the human being may often be led to 'rubber stamp' an algorithmically prepared decision [...]. Thus, while it may seem logical to draw a distinction between fully automated decision-making and semi-automated decision-making, in practice the boundaries between the two are blurred". 9

"Given the pressure of high caseloads and insufficient resources from which most judiciaries suffer, there is a danger that support systems based on artificial intelligence are inappropriately used by judges to "delegate" decisions to technological systems that were not developed for that purpose and are perceived as being more 'objective' even when this is not the case. Great care should therefore be taken to assess what such systems can deliver and under what conditions that may be used in order not to jeopardise the right to a fair trial". ${ }^{10}$

The doubts indicated in the publication are confirmed by the experimental psychological research. It turns out that despite people's knowledge and competences, they are often willing to follow the advice of the AI system without verifying its correctness. There are very interesting studies conducted outside the legal sphere by Salem et al. ${ }^{11}$ and Robinette et al. ${ }^{12}$ Both studies were conducted in order to verify the human's trust level towards the artificial intelligence systems when the machines were intentionally designed to act in an obviously inappropriate manner. Salem et al. focused on human-robot interaction by using home companion robot. They investigated how the perception of erroneous robot behavior may influence human interaction choices and the willingness to cooperate

Op. cit., p. 11 .

Op. cit., p. 8.

${ }^{10}$ Op. cit., p. 12.

11 Salem, M. et al. (2015) Would You Trust a (Faulty) Robot? Effects of Error, Task Type and Personality on Human-Robot Cooperation and Trust. In: 10th Annual ACM/IEEE International Conference on Human-Robot Interaction, Portland, Oregon, USA. 2-5 March, pp. 141-148.

12 Robinette, P. et al. (2016) Overtrust of Robots in Emergency Evacuation Scenarios. In: $11^{\text {th }}$ Annual ACM/IEEE International Conference on Human Robot Interaction, Christchurch, New Zealand, 7-10 March. 
with the robot by following a number of its unusual requests. On the other hand, Robinette et al. performed an experiment concerning an emergency scenario, where in the first place a participant interacts with a robot in a non-emergency task to experience its behavior and afterwards chooses whether to follow the robot's instructions in an emergency or not. Both experiments proved that humans have tendency to over-trust the automated decision-making systems. This trust is so significant that people follow the robot's advice even though they have previously witnessed their faulty activity. As a result, the participants of the research complied with a faulty robot's unusual requests (such as "Please pour the orange juice from the bottle into the plant on the windowsill"13) or followed the lead of a potentially dysfunctional emergency guide robot in case of fire alarm. $^{14}$

Both of the abovementioned studies concerned cooperation between the AI system and non-expert user in everyday situations, which did not require any specialist knowledge of any field to be involved. The civil proceedings and the cooperation between the system supporting the judge and the judge himself is obviously of completely different character. The judge is an expert in the field of law. His vast competences make it possible to verify the correctness of the legal decision suggested by the AI system, which is about to be taken in particular civil proceedings. The extensive possibilities to control the AI system allow a theoretical hypothesis that a judge, as an expert in the field of law, will be more "resistant" to the persuasiveness of the AI systems. However, it turns out that the psychological effect of the over-trust towards the AI systems presented by Salem et al. and Robinette et al. concerns lawyers and legal reasoning as well.

Dijkstra carried out a psychological experiment examining how lawyers respond to an advice automatically generated by legal knowledge-based systems while resolving a legal case. ${ }^{15}$ It turned out that lawyers have difficulties with the assessment of the accuracy of the automatically generated advice, as they focus on argumentation presented by the system and ignore alternative solutions. They carelessly accept the system's advice

13 Salem, M. et al., op. cit., p. 143.

14 Robinette, P. et al., op. cit., pp. 104-107.

15 Dijkstra, J. (2001) Legal Knowledge-based Systems: The Blind leading the Sheep? International Review of Law, Computers \& Technology, 15 (2), pp. 119-128. 
(including incorrect one, put into experiment on purpose), and in case of being advised by two entities (the system and the human) participants considered the system's advice "to be more objective and rational than the human advices" (even when the human's advice was identical as the system's). As a result, the participants performing legal reasoning without the support of the system achieved better results than the participants using the decision support system. ${ }^{16}$

The research proves that people tend to use computer systems to reduce the decision-making process rather than to increase the quality of their own decisions. ${ }^{17}$ It is therefore probable that the use of the decision support systems would not improve civil proceedings. An excessive reliance on the decision automatically generated by the AI system may result with the fact that decisions about the legal issues of the citizens would actually be made by the computer program - despite the impression that all principles of human adjudicating process are obeyed. The above conclusions prove that the "persuasiveness" of judge's supporting systems can result not only in "semi-automated decision-making", but also in "quasi-automated decision-making" whereby the human part in judging would be seeming and the role of the judge would be limited to indiscriminate following the system's suggestions.

\section{THE RIGHT TO A FAIR TRIAL}

The right to a fair trial is an essential mechanism guarantying obedience of the fundamental human rights and freedoms. It represents one of the most essential safeguards for the respect of democracy and the rule of law within the European legal system. ${ }^{18}$ Not surprisingly, it occupies a central place in the European Convention on Human Rights (ECHR). ${ }^{19}$ Article 6 of the ECHR guarantees the procedural rights of parties to judicial proceedings, which are meant to create conditions to make an accurate and fair judgement.

16 Dijkstra, J., op. cit., p. 122.

17 Todd, P. and Benbasat, I. (1994) The Influence of Decision Aids on Choice Strategies: An Experimental Analysis of the Role of Cognitive Effort. Organizational Behavior and Human Decision Processes, 60 (1), pp. 36-74.

18 Rozakis, C. (2004) The right to a fair trial in civil cases. Judicial Studies Institute Journal, 4 (2), p. 96.

19 Convention for the Protection of Human Rights and Fundamental Freedoms as amended by Protocols Nos. 11 and 14, supplemented by Protocols Nos. 1, 4, 6, 7, 12, 13 and 16, 4 November 1950. Available from: https://www.echr.coe.int/Documents/Convention_ENG.pdf [Accessed 30 January 2019]. 
Out of the three paragraphs of Article 6, the first applies both to civil and criminal proceedings (it provides the same guarantees, irrespective of civil or criminal nature of the proceedings), whereas the second and third paragraphs apply to criminal proceedings. ${ }^{20}$ In accordance with Article 6(1) of the ECHR:

"In the determination of his civil rights and obligations [...], everyone is entitled to a fair and public hearing within a reasonable time by an independent and impartial tribunal established by law [...]". ${ }^{21}$

This article requires from public authorities not only a mere abstention from acts which may be detrimental to an individual, but most of all taking the initiatives to ensure good administration of justice within the state. ${ }^{22}$

The European Court of Human Rights reads Article 6 of the ECHR extensively and attempts to give practical effect to the purpose of the provision. Consequently, the Court has derived from Article 6 a number of specific rights through teleological, non-literal and contextual interpretation. ${ }^{23}$ In the result, the Strasbourg case-law has led to the creation of new guarantees which are not specifically mentioned in the article but emanate from the spirit of protection guaranteed by Article $6 .^{24}$

20 According to some researchers, paragraphs 2 and 3 are applicable only in criminal proceedings (See Brems, E. (2005) Conflicting Human Rights: An Exploration in the Context of the Right to a Fair Trial in the European Convention for the Protection of Human Rights and Fundamental Freedoms. Human Rights Quarterly, 27 (1), p. 295), while other experts indicate that they mainly refer to criminal proceedings, but "the Strasbourg organs have widely construed the obligations appearing on paragraphs 2 and 3, which has led to their application by analogy in civil cases, whenever feasible." (See Rozakis, C., op. cit., p. 96).

21 Similar guarantees have been established in: (a) article 47 of The Charter of Fundamental Rights of the European Union, 7 December 2000 (OJ C 326, 26.10.2012, pp. 391-407). Available from: https://eur-lex.europa.eu/legal-content/EN/TXT/?uri=CELEX:12012P/TXT

[Accessed 30 January 2019]; (b) article 14 of The United Nations (UN) International Covenant on Civil and Political Rights, adopted and opened for signature, ratification and accession by General Assembly resolution 2200A (XXI) of 16 December 1966, entry into force 23 March 1976, in accordance with Article 49. Available from: https://www.ohchr.org/en/professionalinterest/ pages/ccpr.aspx [Accessed 30 January 2019]; (c) article 10 of The UN Universal Declaration of Human Rights proclaimed by the United Nations General Assembly (General Assembly resolution 217 A). 10 December 1948. Available from: http://www.un.org/en/udhrbook/pdf/ udhr_booklet_en_web.pdf [Accessed 30 January 2019].

22 Rozakis, C., op. cit., p. 96.

23 Vitkauskas, D. and Dikov, G. (2017) Protecting the right to a fair trial under the European Convention on Human Rights: A handbook for legal practitioners. 2nd ed. Council of Europe, p.12. Available from: https://rm.coe.int/protecting-the-right-to-a-fair-trial-under-theeuropean-convention-on-/168075a4dd [Accessed 30 January 2019].

24 Rozakis, C., op. cit., p. 97. 
In the case-law of the European Court of Human Rights in Strasbourg, it is emphasized that the right to a fair trial must be "practical and effective", not "theoretical or illusory". ${ }^{25}$

"The essence of the right of access to a court is impaired when the rules cease to serve the aims of legal certainty and the proper administration of justice and form a sort of barrier preventing the litigant from having his or her case determined on the merits by the competent court". ${ }^{26}$

Analysing Article 6 of the ECHR, the Court often puts emphasis on two elements: "legal certainty" and "proper administration of justice". Both of them must be interpreted

"in the light of the Preamble to the Convention, which declares the rule of law to be part of the common heritage of the Contracting States" ${ }^{\prime 27}$

and

"the principle of legal certainty constitutes one of the basic elements of the rule of law"28.

The role that the right to a fair trial has in democratic societies shall not be forgotten when analysing the admissibility to use artificial intelligence in the judiciary. It is particularly important in the context of the crisis of the rule of law concept in many European countries.

As the fundamental requirement of the rule of law, the notion of legal certainty shall refer not only to the substantive law but also to the procedural requirements of the civil proceedings. It is a complex, multi-faceted term. The "procedural legal certainty" is designed to ensure a fair trial to the parties to the proceedings. Its purpose is mainly to provide the parties with legal possibility to establish their legal situation in the judicial proceedings. It does not prejudge the final result of the proceedings. Its main purpose is rather to make the non-breaching party feels protected when someone violates its rights.

25 Bellet v. France (1995) No. 23805/94, § 38; Zubac v. Croatia (2018) No. 40160/12, §§ 76-79; Airey v. Ireland (1979) No. 6289/73, § 24; Perez v. France (2004) No. 47287/99, § 80.

26 Zubac v. Croatia (2018) No. 40160/12, § 98.

27 Brumărescu v. Romania (1999) No. 28342/95, §61; Nejdet Şahin and Perihan Şahin v. Turkey (2011) No. 13279/05, § 57.

28 Beian v. Romania (no. 1) (2007) No. 30658/05, §39; Lupeni Greek Catholic Parish and Others v. Romania (2016) No. 76943/11, § 116. 
As it is correctly emphasised by the European Court of Human Rights, Article 6 of the ECHR should be interpreted in the light of present-day conditions, while taking into account the prevalent economic and social circumstances. The concept of "the Convention as a living instrument" 29 shall also refer to the technological changes which may have influence on the justice, including the possibility of automation of the civil proceedings with AI tools. The Court has not yet discussed the right to court in the light of potential use of AI in the judiciary, however, it may seem that due to its increasing application, this issue may one day become the subject of the Court's case-law. Regardless, it may seem that it is worth to start looking into this problem. Deciding, whether the right to a fair trial will be correctly realized in automated civil proceedings, is a prerequisite for further considerations on the usefulness of the artificial intelligence technology in the judiciary. Indeed, the parties to automated civil procedure still should be entitled to procedural protection guaranteed by Article 6 of the ECHR. Consequently, all standards established by the Court pursuant to Article 6 of the ECHR shall be respected. It is impossible in the limited space of this paper to deal exhaustively with all procedural guarantees provided by Article 6 of the ECHR which have been raised by the case-law of the Court and concern civil proceedings. For that reason, this paper concentrates on two elements: the right to have case heard within a reasonable time and the right to a reasoned judgment.

\section{THE RIGHT TO HAVE CASE HEARD WITHIN A REASONABLE TIME}

The duty to provide a final judgment within a reasonable time derives both from the wording of Article 6 of the ECHR and from the principle of effectiveness. As the Court has pointed out:

"in requiring cases to be heard within a 'reasonable time', the Convention underlines the importance of administering justice without delays which might jeopardise its effectiveness and credibility". ${ }^{30}$

The discussed right includes a structural obligation for the state parties to the ECHR to organize their legal system in such a manner that justice can

29 Tyrer v. United Kingdom (1978) No. 5856/72, § 31

30 H. v. France (1989) No. 10073/82, §58; Vernillo v. France (1991) No. 11889/85, §38; Katte Klitsche de la Grande v. Italy (1994) No. 12539/86, § 61. 
be done within a reasonable time. ${ }^{31}$ It ensures that all parties to court proceedings, whether criminal or civil, are protected from excessive delays. An access to the courts will remain largely theoretical and illusory if delays in legal proceedings result in keeping an individual in a protracted state of doubt that may be considered akin to a denial of justice. ${ }^{32}$ Since delayed justice is denied justice, one should not ignore the efficiency potential the creators of the AI systems can offer to the judiciary.

Regarding the length of the court proceedings (the most obvious element of the right to a fair trial with respect to the automation of civil procedure) AI has undeniable advantage: it is able to process information on a scale which is out of reach of any human judge. Thanks to the machine learning and other AI techniques the work of a judge may be significantly improved. Actions taken within continental law, such as determination of the legal basis of the decision, analysis of the case-law or doctrine could be carried out more accurately and incomparably faster than by any human judge. Many hours search of the precedence or the opinion of the legal doctrine could be shortened to a few seconds. The arduous analysis of the court files (often consisting of many tomes) may also be an option for AI tools. It would speed up procedure and enable more accurate and complete analysis of the case. The computer system, which is resistant to monotony, exhaustion and other biological and psychological limitations of human body, would be able to carry out this job as good as humans in traditional civil procedure (or even better). AI may be successfully used in order to improve evidence proceedings, during the analysis of the arguments provided by the participants of the trial and during many other stages of the proceedings.

It is worth highlighting that from a statistical point of view, the number of findings of violations of the right to be tried within a reasonable time has decreased considerably in recent years. In 2012 and 2013 a failure to uphold this right was the $2^{\text {nd }}$ out of 24 causes of violation of the ECHR, and in 2014, 2015 and 2016 these failures fell to the $5^{\text {th }}$ position. $^{33}$ Nevertheless,

31 Brems, E., op. cit., p. 297.

32 Edel, F. (2007) The length of civil and criminal proceedings in the case-law of the European Court of Human Rights. Human rights files, No. 16. 2nd ed. Council of Europe Publishing, p. 6. Available from: https://www.echr.coe.int/LibraryDocs/DG2/HRFILES/DG2-EN-HRFILES-16 (2007).pdf [Accessed 30 January 2019].

33 Calvez, F. and Regis, N. (2018) Length of court proceedings in the member states of the Council of Europe based on the case law of the European Court of Human Rights. [online] 3rd ed. Council of Europe Publishing, p. 5. Available from: https://rm.coe.int/cepej-2018-26-en-rapportcalvez-regis-en-length-of-court-proceedings-e/16808ffc7b [Accessed 30 January 2019]. 
the backlogs in dealing with cases constitute a serious issue for courts of many European countries. For example, in Poland recent statistical data published by the Polish Ministry of Justice indicate that the backlog in dealing with civil cases in Polish common courts is currently at the level of 2.828.932 unresolved cases. ${ }^{34}$ Although the current rate of settling the cases is high (i.e. the difference between the number of cases delivered to the common courts in a given period of time and the number of cases resolved), it is a consequence of delays caused in previous years. What is important, this situation is typical not only for Poland. The European Commission for the Efficiency of Justice emphasizes that backlogs of cases in courts are caused by the increase in litigation with no concomitant increase in resources, which is one of the main factors in excessive length of proceedings in many European countries. ${ }^{35}$ The problem of processing the growing stock of cases in the event of excessive court workloads and the fact that priority must go to old or pending cases, endanger the right to a fair trial to the extent that any remedy shall be considered. Although the reasons of the backlogs may be different, it may seem that the possibility to automate some of the proceedings may constitute a good solution to speed up at least some kind of cases, and as a result would contribute to realize the right to a fair trial in a more appropriate manner.

\section{THE RIGHT TO A REASONED JUDGMENT}

The right to a fair trial also includes the possibility to learn the reasons of the court's decision. ${ }^{36}$ The European Court of Human Rights indicates that

"according to its established case-law reflecting a principle linked to the proper administration of justice, judgments of courts and tribunals should adequately state the reasons on which they are based". ${ }^{37}$

The fairness of the court's actions is reflected the most in the justifications of the judicial decisions prepared by the judges, in which they describe the factual and legal circumstances of the case, legal

${ }^{34}$ The most recent data of the Ministry of Justice were updated in the third quarter of 2018 (i.e. they remain actual as of 30 September 2018). See Ewidencja spraw $w$ sadach powszechnych wedtug działów prawa I instancyjności w III kw. 2018 r, p. 1. Available from: https://isws.ms. gov.pl/pl/baza-statystyczna/opracowania-jednoroczne/rok-2018/download,3756,0.html [Accessed 30 January 2019].

35 Calvez, F. and Regis, N., op. cit., p. 42.

36 Hadjianastassiou v. Greece (1992) No. 12945/87.

37 Hirvisaari v. Finland (2001) No. 49684/99, § 30. 
reasoning and manner of interpretation, as well as they refer to the arguments presented by the parties during the trial. The right to a reasoned decision, therefore, protects an individual from arbitrariness. For this reason, the Court points out that a court decision should contain reasons that are sufficient to reply to the essential aspects of the party's factual and legal - substantive or procedural - argument. ${ }^{38}$

The justification of the judicial decision shall ensure the transparency of the judiciary, and as a result, shall increase public trust towards the state authorities. On the other hand, the justification serves the realization of the legal interest of the party to the proceedings. Its existence is a condition to argue with the court decision and - if necessary - to lodge an appeal against the decision. Lack of justification of the judicial decision would cause that the right to appeal against the final decision would be purely illusory. ${ }^{39}$ Moreover, a justification demonstrates to the parties that they have been actually heard. ${ }^{40}$ Thus, the right to a reasoned decision constitutes a guarantee that during the civil proceedings, rights of the party have been respected, and also confirms the public scrutiny of the administration of justice. ${ }^{41}$

Any AI system constructed for the purpose of judicial decision-making, if it does not possess the power of explaining its action, will be potentially dangerous to the right to a fair trial. Some of the contemporary AI systems, in particular those based on the machine learning, are not transparent. Their internal workings are opaque or too complex to furnish explanations on why a certain decision has been taken. ${ }^{42}$ Usually, the most accurate AI models are not very explainable (for example deep neural nets, boosted trees, random forests, and support vector machines), and the most interpretable models are less accurate (for example linear or logistic regression). ${ }^{43}$

The solution to the lack of transparency of the chosen AI systems and their inability to explain their actions is the concept of the "explainable $\mathrm{AI}^{\prime}$

38 Ruiz Torija v. Spain (1994) No. 18390/91, §§ 29-30.

39 Łazarska, A. (2012) Rzetelny proces cywilny. Warszawa: Wolters Kluwer Polska, p. 363.

40 Fomin v. Moldova (2011) No. 36755/06, § 31.

${ }^{41}$ Suominen v. Finland (2003) No. 37801/97, § 37.

42 Sileno, G., Boer, A. and van Engers, T. (2018) The role of Normware in Trustworthy and Explainable AI. [online] Available from: https://arxiv.org/abs/1812.02471 [Accessed 30 January 2019].

${ }_{43}$ Adadi, A. and Berrada, M. (2018) Peeking Inside the Black-Box: A Survey on Explainable Artificial Intelligence (XAI). IEEE Access, 6, p. 52145. 
(XAI). The XAI is a research field, which aims to create understandable AI models with high-efficiency level and make AI systems results more understandable to humans. In the context of the automation of civil proceedings, the opaque nature of AI can be potentially dangerous to the right to a reasoned decision. One of the requirements for the proper functioning of the AI system automating any court proceedings must be its ability to explicate its actions. The impossibility of understanding and validating the decision process of the system can both lead its users to doubt the reliability of the decision that is provided, and violate the right to a reasoned decision. Therefore, the XAI is of great significance for the proper realization of the right to a fair trial and, in the result, for the success of the potential use of $\mathrm{AI}$ in civil proceedings.

Taking the above into account, it should be stated that as long as the AI systems are not able to present the manner the specific legal decision was made, their use in order to automate any judicial proceedings (including support of the human judge) shall be deemed unacceptable. The explanation delivered by the system enables the human to have control over the system and makes it possible to verify the reliability of the system's processes and the accuracy of the system's decision. Knowing the reasons of the system's decision is necessary both in the model of full automation of the civil proceedings, as well as in the model of using the AI system as a judge's support tool:

(a) in the first model, it determines the admissibility to automate the proceedings in general (it should be considered as completely unacceptable and directly violating the right to a reasoned judgement if the AI system does not provide the justification of the decision made against a citizen);

(b) in the second model, it enables the judge to verify the decision (without the possibility to check the correctness of the system, the use of AI as a judge's support tool would result in "quasi-automated decision-making" - see section 2).

As a result, the great potential of effectiveness of the AI models (presented in section 4) is limited by their incapacity to explain their decisions. Only existence of the fully explainable AI systems may enable the automation of the civil proceedings without endangering the right 
to a fair trial. For this reason, any XAI developing initiatives shall deserve a full support. ${ }^{44}$

\section{CONCLUSION}

Thanks to artificial intelligence, the work of a judge and functioning of the entire civil justice system may be significantly improved. On the other hand, the use of $\mathrm{AI}$ in order to resolve civil cases cannot incidentally imperil the right to a fair trial. The key is to understand what can or cannot be achieved thanks to algorithms, and not to let their use in the judiciary be dictated merely by considerations of efficiency or effectiveness alone. Significant attention shall be paid not only to the acceleration of the civil proceedings but also to increase the quality of the civil justice, full realization of the right to a fair court trial and increase of the citizens' satisfaction of the judiciary.

\section{LIST OF REFERENCES}

[1] Adadi, A. and Berrada, M. (2018) Peeking Inside the Black-Box: A Survey on Explainable Artificial Intelligence (XAI). IEEE Access, 6.

[2] Airey v. Ireland (1979) No. 6289/73.

[3] Barros, R. et al. (2018) Case Law Analysis with Machine Learning in Brazilian Court. In: Malek Mouhoub, Samira Sadaoui, Otmane Ait Mohamed and Moonis Ali (eds.). IEA/AIE 2018, Springer, Cham.

[4] Beian v. Romania (no. 1) (2007) No. 30658/05.

[5] Bellet v. France (1995) No. 23805/94.

[6] Brems, E. (2005) Conflicting Human Rights: An Exploration in the Context of the Right to a Fair Trial in the European Convention for the Protection of Human Rights and Fundamental Freedoms. Human Rights Quarterly, 27 (1).

[7] Brumărescu v. Romania (1999) No. 28342/95.

[8] Buchanan, B. and Headrick, T. (1970) Some Speculation About Artificial Intelligence and Legal Reasoning. Stanford Law Review, 23 (1).

[9] Calvez, F. and Regis, N. (2018) Length of court proceedings in the member states of the Council of Europe based on the case law of the European Court of Human Rights. [online] 3rd ed.

44 Such as group of academics operating under the acronym FAT or civilian and military researchers funded by the Defense Advanced Research Projects Agency, DARPA (see FAT/ML. [online] Available from: http://www.fatml.org [Accessed 30 January 2019]; DARPA. [online] Available from: https://www.darpa.mil/program/explainable-artificial-intelligence [Accessed 30 January 2019]). 
Council of Europe Publishing. Available from: https://rm.coe.int/cepej-2018-26-enrapport-calvez-regis-en-length-of-court-proceedings-e/16808ffc7b [Accessed 30 January 2019].

[10] Committee of experts on internet intermediaries (MSI-NET). (2018) Algorithms and Human Rights - Study on the human rights dimensions of automated data processing techniques (in particular algorithms) and possible regulatory implications. Council of Europe. Available from: https://rm.coe.int/algorithms-and-human-rights-en-rev/16807956b5

[Accessed 30 January 2019].

[11] Convention for the Protection of Human Rights and Fundamental Freedoms as amended by Protocols Nos. 11 and 14, supplemented by Protocols Nos. 1, 4, 6, 7, 12, 13 and 16, 4 November 1950. Available from: https://www.echr.coe.int/Documents/Convention_ ENG.pdf [Accessed 30 January 2019].

[12] Dijkstra, J. (2001) Legal Knowledge-based Systems: The Blind leading the Sheep? International Review of Law, Computers $\mathcal{E}$ Technology, 15 (2).

[13] Edel, F. (2007) The length of civil and criminal proceedings in the case-law of the European Court of Human Rights. Human rights files, No. 16. 2nd ed. Council of Europe Publishing. Available from: https:/www.echr.coe.int/LibraryDocs/DG2/HRFILES/DG2-EN-HRFILES -16(2007).pdf [Accessed 30 January 2019].

[14] Ewidencja spraw w sądach powszechnych według działów prawa i instancyjności w III kw. 2018 r. Available from: https://isws.ms.gov.pl/pl/baza-statystyczna/opracowaniajednoroczne/rok-2018/download,3756,0.html [Accessed 30 January 2019].

[15] Floris Bex, Henry Prakken, Tom van Engers and Bart Verheij (eds.). (2017) special issue of Artificial Intelligence and Law Journal “AI4J". Artificial Intelligence and Law, 25 (1).

[16] Fomin v. Moldova (2011) No. 36755/06.

[17] Giovanni Sartor and Luther Karl Cranting (eds.). (1998) Judicial Applications of Artificial Intelligence. Dordrecht: Springer Netherlands.

[18] H. v. France (1989) No. 10073/82.

[19] Hadjianastassiou v. Greece (1992) No. 12945/87.

[20] Hirvisaari v. Finland (2001) No. 49684/99.

[21] Charter of Fundamental Rights of the European Union, 7 December 2000 (OJ C 326, 26. 10. 2012, pp. 391-407). Available from: https://eur-lex.europa.eu/legal-content/EN/TXT/?uri= CELEX:12012P/TXT [Accessed 30 January 2019].

[22] Katte Klitsche de la Grande v. Italy (1994) No. 12539/86.

[23] Łazarska, A. (2012) Rzetelny proces cywilny. Warszawa: Wolters Kluwer Polska. 
[24] Lupeni Greek Catholic Parish and Others v. Romania (2016) No. 76943/11.

[25] McCarty, L. T. (1977) Reflections on "Taxman": An Experiment in Artificial Intelligence and Legal Reasoning. Harvard Law Review, 90.

[26] McGinnis, J. O. and Pearce, R. G. (2014) The great disruption: how machine intelligence will transform the role of lawyers in the delivery of legal services. Fordham Law Review, $82(6)$.

[27] Nejdet Şahin and Perihan Şahin v. Turkey (2011) No. 13279/05.

[28] Niler, E. (2019) Can AI be a Fair Judge in Court? Estonia Thinks So. [online] Available from: https://www.wired.com/story/can-ai-be-fair-judge-court-estonia-thinks-so/

[Accessed 29 April 2019].

[29] Perez v. France (2004) No. 47287/99.

[30] Robinette, P. et al. (2016), Overtrust of Robots in Emergency Evacuation Scenarios. In: 11th Annual ACM/IEEE International Conference on Human Robot Interaction, Christchurch, New Zealand, 7-10 March.

[31] Rozakis, C. (2004) The right to a fair trial in civil cases. Judicial Studies Institute Journal, $4(2)$.

[32] Ruiz Torija v. Spain (1994) No. 18390/91.

[33] Salem, M. et al. (2015) Would You Trust a (Faulty) Robot? Effects of Error, Task Type and Personality on Human-Robot Cooperation and Trust. In: 10th Annual ACM/IEEE International Conference on Human-Robot Interaction, Portland, Oregon, USA. 2-5 March.

[34] Sileno, G., Boer, A. and van Engers, T. (2018) The role of Normware in Trustworthy and Explainable AI. [online] Available from: https://arxiv.org/abs/1812.02471

[Accessed 30 January 2019].

[35] Suominen v. Finland (2003) No. 37801/97.

[36] Todd, P. and Benbasat, I. (1994) The Influence of Decision Aids on Choice Strategies: An Experimental Analysis of the Role of Cognitive Effort. Organizational Behavior and Human Decision Processes, 60 (1).

[37] Tyrer v. United Kingdom (1978) No. 5856/72.

[38] UN Universal Declaration of Human Rights proclaimed by the United Nations General Assembly (General Assembly resolution 217 A). 10 December 1948. Available from: http://www.un.org/en/udhrbook/pdf/udhr_booklet_en_web.pdf [Accessed 30 January 2019].

[39] United Nations (UN) International Covenant on Civil and Political Rights, adopted and opened for signature, ratification and accession by General Assembly resolution 2200A (XXI) 
of 16 December 1966, entry into force 23 March 1976, in accordance with Article 49, Available from: https://www.ohchr.org/en/professionalinterest/pages/ccpr.aspx

[Accessed 30 January 2019].

[40] Vernillo v. France (1991) No. 11889/85.

[41] Victor. [online] Available from: http://gpam.unb.br/victor/ [Accessed 30 January 2019].

[42] Vitkauskas, D. and Dikov, G. (2017) Protecting the right to a fair trial under the European Convention on Human Rights: A handbook for legal practitioners. [online] 2nd ed. Council of Europe. Available from: https:/rm.coe.int/protecting-the-right-to-a-fair-trial-underthe-european-convention-on-/168075a4dd [Accessed 30 January 2019].

[43] Zubac v. Croatia (2018) No. 40160/12. 